\title{
Influence of native and exotic tree plantations on biophysical indicators in the Brazilian Savanna ${ }^{1}$
}

\author{
Bruno Vargas Adorno 2 , Sybelle Barreira ${ }^{3}$, \\ Manuel Eduardo Ferreira ${ }^{4}$, Gabriel Alves Veloso ${ }^{5}$
}

\section{ABSTRACT}

The monitoring of biophysical indicators can show the conservation or recovery status of a landscape. This study aimed to analyze the influence of tree plantations on the dynamics of biophysical indicators (albedo, NDVI, surface temperature and evapotranspiration), in an experimental area of the Cerrado biome (Brazilian Savanna), by applying remote sensing techniques and the SEBAL algorithm. The indicators dynamics were given as a function of changes in the land use, while assessing the response of the environment to the planting of tree species. SEBAL data on areas that underwent changes in land use and cover during this period were analyzed. In the surroundings of the experimental area, albedo and surface temperature decreased in agricultural and exposed soil areas converted to tree plantations, while the NDVI and evapotranspiration increased. The opposite happened in the conversion of native areas destined to agriculture and livestock. In the experimental area, it was confirmed that the plantations contributed not only to the decrease in the surface and albedo temperature, but also to the increase in the NDVI and evapotranspiration. This confirms the positive influence of tree planting in rural properties of the Cerrado as a support to environmental regularization and more sustainable agricultural systems. Moreover, it highlights the potential of the technique applied to assist in monitoring Cerrado ecosystems in areas larger than those commonly monitored in the field.

KEYWORDS: Remote sensing, legal reserve, land use and cover change.

\section{INTRODUCTION}

More and more global targets have been established every year due to the increasing loss of ecosystem services (Sarukhán \& Whyte 2005, Wood

\section{RESUMO}

Influência de plantios de árvores nativas e exóticas sobre indicadores biofísicos no Cerrado

O monitoramento de indicadores biofísicos pode atestar o estado de conservação ou de recuperação de uma paisagem. Objetivou-se avaliar a influência do plantio de árvores na dinâmica de indicadores biofísicos (albedo, NDVI, temperatura de superfície e evapotranspiração), em área experimental no bioma Cerrado, por meio de técnicas de sensoriamento remoto e uso do algoritmo SEBAL. Verificou-se a dinâmica dos indicadores conforme mudanças de uso do solo, avaliando-se a resposta do ambiente aos plantios de espécies arbóreas. Foram analisados os dados do SEBAL sobre áreas que sofreram mudanças de uso e cobertura da terra nesse período. No entorno da área experimental, albedo e temperatura de superfície diminuíram em áreas de agricultura e solo exposto convertidas em plantios de arbóreas, enquanto NDVI e evapotranspiração aumentaram. O contrário aconteceu na conversão de áreas nativas destinadas à agropecuária. $\mathrm{Na}$ área experimental, confirmou-se que os plantios contribuíram não só para a diminuição da temperatura de superfície e do albedo, mas também com o aumento do NDVI e da evapotranspiração. Confirmou-se, assim, a influência positiva do plantio de árvores em propriedades rurais no Cerrado, como suporte à regularização ambiental e sistemas agrícolas mais sustentáveis. Além disso, destaca-se o potencial da técnica utilizada para auxiliar no monitoramento de ecossistemas do Cerrado, em áreas maiores do que aquelas geralmente monitoradas em campo.

PALAVRAS-CHAVE: Sensoriamento remoto, reserva legal, mudança de uso e cobertura do solo.

et al. 2018). This is an answer to the growing pressure on natural resources, usually replaced by urban areas and commodity crops to meet the increasing demand for food (Cumming \& Von Cramon-Taubadel 2018, UN 2018). Brazil is a privileged country in this

\footnotetext{
${ }^{1}$ Received: Oct. 02, 2020. Accepted: Feb. 02, 2021. Published: Mar. 22, 2021. DOI: 10.1590/1983-40632021v5165815.

${ }^{2}$ Instituto Nacional de Pesquisas Espaciais, Divisão de Observação da Terra e Geoinformática, São José dos Campos, SP, Brasil. E-mail/ORCID: bruno.adorno@inpe.br/0000-0003-0302-7834.

${ }^{3}$ Universidade Federal de Goiás, Escola de Agronomia, Setor de Engenharia Florestal, Goiânia, GO, Brasil. E-mail/ORCID: sybelle.barreira@gmail.com/0000-0003-1482-2411.

${ }^{4}$ Universidade Federal de Goiás, Instituto de Estudos Socioambientais, Goiânia, GO, Brasil. E-mail/ORCID: manuel@ufg.br/0000-0003-4516-6373.

${ }^{5}$ Universidade Federal do Pará, Faculdade de Geografia, Altamira, PA, Brasil. E-mail/ORCID: gabrielveloso.geo@gmail.com/0000-0002-3655-4166.
} 
regard, because it still has extensive natural areas with high biodiversity, especially in the Amazon.

Notwithstanding, many of these areas are under intense conversion, with high deforestation records. This is the case of the Cerrado (Brazilian Savanna) (Brasil 2018). Although considered a biodiversity hotspot (CEPF 2018), this biome has been negatively impacted by the advancement of the agricultural frontier (Alencar et al. 2020). This advancement has initiated in the second half of the twentieth century by government programs such as the Nipo-Brazilian Cooperation Program for the Development of Cerrados (Prodecer) (Kazuhiro 2000). Additionally, water scarcity on hydrographic systems, such as the Araguaia-Tocantins and Meia Ponte, is more severe each year (Mascarenhas et al. 2009, Coe et al. 2011, Latrubesse et al. 2019).

To mitigate these adversities, the union of government efforts, civil society and scientific community in decision making and territorial governance is urgent. In the political environment, the Federal Government has promoted management and supporting tools to the regularization of legal reserves and permanent preservation areas, and has encouraged more sustainable production systems, such as agroforestry systems (Brasil 2012). Recently, another widespread action ("Together for Araguaia" or, in Brazilian Portuguese, Juntos pelo Araguaia) has been dealing with forest restoration at the head of the Araguaia River to expand the water availability in areas with higher recharging potential. This action is supported by the Ministry of Regional Development, universities and research institutes (Ferreira Neto 2018).

To the date, the monitoring of ecological indicators for ecosystem restoration has been usually performed with field (in loco) surveys. This process includes high logistical effort and is limited in spatial terms (i.e., coverage of small sample areas). In this context, it becomes interesting and feasible to associate environmental analyses via remote sensing, especially in more extensive areas (Kumar et al. 2015). Sensors on board satellites or aircrafts make it possible to measure biophysical indicators such as albedo, normalized difference vegetation index (NDVI), surface temperature and actual evapotranspiration, which are influenced by the types of land use and cover (Veloso et al. 2017, Veloso et al. 2020).

Albedo corresponds to the solar radiation reflection of a given target. Vegetation tends to present low albedo, since it favors the absorption of radiation for photosynthesis (Bala et al. 2007), which also means lower atmospheric heating. The NDVI, corresponding to the normalized ratio between reflectances in the near infrared band and red band, indicates more photosynthetically active vegetation areas with positive values (Ponzoni et al. 2012), showing their level of degradation or conservation. These and other indicators, detailed by Veloso (2014) and Veloso et al. (2020), can measure absorbed radiation. This radiation contributes to measure both the increased surface temperature, in the form of sensible heat, and the phenomena occurring in vegetation areas (such as evapotranspiration), in the form of latent heat (Veloso 2020). That is, these indicators are greatly sensitive to the supply of ecosystem services and to changes in the land use and cover, being, therefore, important in the monitoring of recovery processes in anthropized areas.

Methods that use surface meteorological data and remote sensing techniques to measure these indicators have been developed. Among them, stands out the estimation of radiation and energy balance by the Surface Energy Balance Algorithm for Land - SEBAL (Bastiaanssen 1995), using satellite images as an input parameter in the model to obtain the actual daily evapotranspiration.

The SEBAL method has some advantages over others (e.g., Simple Algorithm for Evapotranspiration Retrieving - SAFER and Mapping Evapotranspiration at High Resolution with Internal Calibration METRIC; Silva et al. 2019a). Some examples are the greater accuracy of this algorithm (Menezes et al. 2011); greater number of scientific studies using it; better adjustment to the input parameters, with lower dependence on the use of terrestrial data for model calibration; and the possibility of generating information for each image pixel (Bastiaansen 2010 ).

In this perspective, this study monitored the dynamics of vegetation biophysical indicators (albedo, NDVI, surface temperature and evapotranspiration), in an experimental area of the Cerrado, by applying remote sensing techniques and the SEBAL algorithm.

\section{MATERIAL AND METHODS}

The study was conducted at the Entre Rios

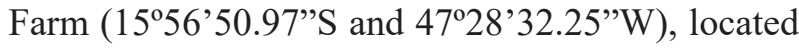


in the Federal District of Brazil (Figure 1). This is an experimental area of the Biomas project, a partnership between the Brazilian Confederation of Agriculture and Livestock (CNA), Brazilian Agricultural Research Corporation (Embrapa) and other interested parties from different Brazilian biomes. The mission of the project is to present to the society, especially to rural producers, tree plantation models for economic purposes and environmental regularization (CNA 2009). Tree species were planted in restricted production areas of permanent preservation and legal reserve, in the last quarter of 2012, in accordance with the Law 12,651 of May 25, 2012 (Brasil 2012) and Law 12,805 of 2013 (Brasil 2013). The aim of this planting was to regularize the rural property and promote the recovery of degraded pastures.

According to the Köppen classification, the climate in the region is Savanna tropical (Aw), with concentrated rainfall from October to April (approximately 1,400 mm, $80 \%$ of the annual total). The relative humidity may range from 20 to $70 \%$, and the average annual temperature is $22{ }^{\circ} \mathrm{C}$ (Silva et al. 2008).
In August 2015, 12 areas where tree species were planted for various purposes were identified and mapped (Table 1). A Garmin satellite-navigation device (model Etrex) was used to collect control points, which supported the subsequent classification of satellite images. In the absence of a local meteorological station for the two analyzed periods, information from the Brazilian National Institute of Meteorology was used (Brasil 2020), referring to the available point closest to the study area, located at the Águas Emendadas Ecological Station, rural area of the Brazilian Federal District (Table 2).

The Surface Energy Balance Algorithm for Land (SEBAL), described in Bastiaanssen (1995), was chosen to generate biophysical indicators for each target, allowing a quantitative comparison between them. The methods for its use in Landsat 5 and Landsat 8 images were detailed by Veloso (2014) and Veloso et al. (2020). The algorithm stands out for its greater accuracy in estimating energy balance and evapotranspiration (Menezes et al. 2011).

Still on the data used in SEBAL, Landsat 5 TM and Landsat 8 OLI/TIRS satellite images were obtained from the United States Geological Service

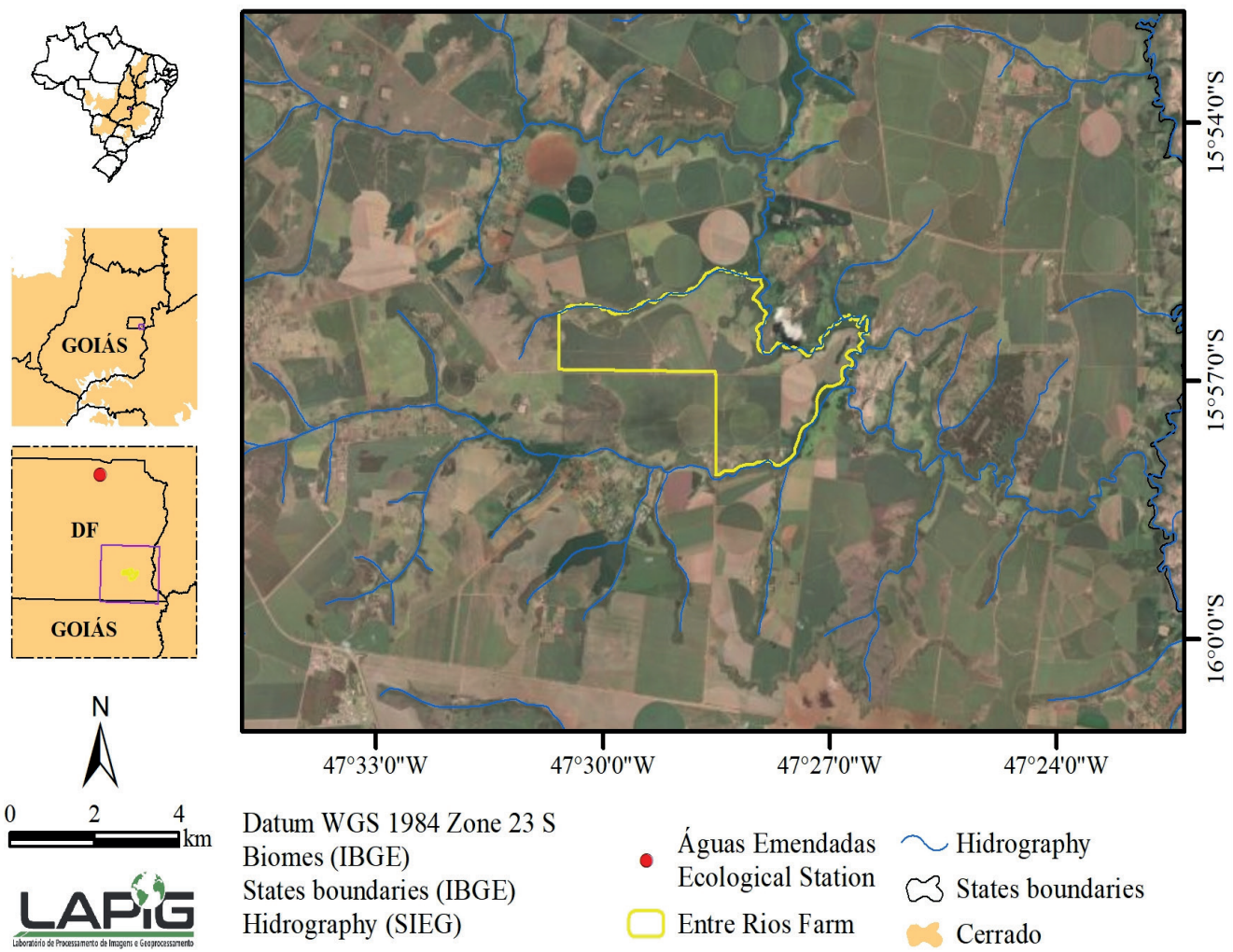

Figure 1. Entre Rios Farm location in the Brazilian Federal District (Biomas Project). 
Table 1. Identification of 12 areas where tree species were planted for various purposes in the Entre Rios Farm, in the Brazilian Federal District.

\begin{tabular}{|c|c|c|c|}
\hline Latitude (S) & Longitude $(\mathrm{W})$ & Planting description & Planting objective \\
\hline-15.936651 & -47.504668 & Cerrado native species - seedlings & Environmental regularization \\
\hline-15.935771 & -47.505690 & Dipteryx alata Vogel plantation & Environmental regularization \\
\hline-15.936924 & -47.505967 & Eucalyptus sp. and Cerrado native species & Environmental regularization \\
\hline-15.936542 & -47.506959 & $\begin{array}{l}\text { Tectona grandis L. f. and Acacia mangium Willd. with } \\
\text { Cerrado native species }\end{array}$ & Environmental regularization \\
\hline-15.936484 & -47.507467 & $\begin{array}{l}\text { Acacia mangium Willd and Hevea brasiliensis (Willd. ex } \\
\text { A. Juss.) Müll. Arg. with Cerrado native species }\end{array}$ & Environmental regularization \\
\hline-15.936187 & -47.504431 & Cerrado fruit species & Environmental regularization \\
\hline-15.944022 & -47.504578 & Cerrado native species - direct seeding & Environmental regularization \\
\hline-15.936863 & -47.503774 & Agroforestry with Khaya sp. & Sustainable production/pasture recovery \\
\hline-15.936493 & -47.503018 & Cerrado native species - direct seeding & Environmental regularization \\
\hline-15.944553 & -47.467334 & Eucalyptus sp. and Cerrado native species - direct seeding & Environmental regularization \\
\hline-15.947581 & -47.470175 & Integrated crop-livestock-forestry systems & Sustainable production/pasture recovery \\
\hline-15.958294 & -47.459053 & Restoration with native and exotic trees & Environmental regularization \\
\hline
\end{tabular}

Table 2. Meteorological data from the Águas Emendadas Ecologial Station for the dates evaluated in the study, similar to the satellite images (Landsat).

\begin{tabular}{lccccc}
\hline $\begin{array}{c}\text { Image acquisition } \\
\text { dates }\end{array}$ & $\begin{array}{c}\text { Temperature } \\
\left({ }^{\circ} \mathrm{C}\right)\end{array}$ & $\begin{array}{c}\text { Relative humidity } \\
(\%)\end{array}$ & $\begin{array}{c}\text { Atmospheric pressure } \\
(\mathrm{Kpa})\end{array}$ & $\begin{array}{c}\text { Wind speed } \\
\left(\mathrm{m} \mathrm{s}^{-1}\right)\end{array}$ & $\begin{array}{c}\text { Global radiation } \\
\left.(\mathrm{W} \mathrm{m})^{-2}\right)\end{array}$ \\
\hline November 4, 2008 & 31.00 & 33.00 & 90.04 & 3.00 & 237.90 \\
September 21, 2015 & 28.90 & 21.00 & 90.22 & 3.40 & 295.30 \\
\hline
\end{tabular}

Source: Brasil (2020). Data were required for the same image acquisition dates.

(USGS 2020) website, corresponding to path 221 , row 71, for November 4, 2008 and September 21, 2015 , respectively. The choice of these images is due to the proximity of the date of data collection in the field. Those with cloud cover of up to $10 \%$ were considered. Another criterion was the dry period, with extremes values of biophysical indicators. Additionally, to increase the chance of observing significant changes in the land use, the analysis considered the oldest image with meteorological data available at the Brazilian National Institute of Meteorology (October 02, 2008) (Brasil 2020).

The data processing was divided into two steps: 1) mapping of land use in the farm and its immediate surroundings (limited by the coordinates $15^{\circ} 50^{\prime} 2.11^{\prime \prime} \mathrm{S}$ and $47^{\circ} 36^{\prime} 13.84$ ' $\mathrm{W}$ in the upper left quadrant and $16^{\circ} 03^{\prime} 30.71^{\prime \prime} \mathrm{S}$ and $47^{\circ} 20^{\prime} 50.22^{\prime} \mathrm{W}$ in the lower right quadrant) for the two images (2008 and 2015), using the study by Sano et al. (2009) as a reference for the interpretation of Cerrado classes; 2) analysis of the images processed by the SEBAL (limited by the coordinates $15^{\circ} 29^{\prime} 20.45^{\prime \prime} \mathrm{S}$ and $47^{\circ} 43^{\prime} 49.75^{\prime \prime} \mathrm{W}$ in the upper left quadrant and $16^{\circ} 09^{\prime} 41.94$ "S and $47^{\circ} 13^{\prime} 46.33^{\prime \prime} \mathrm{W}$ in the lower right quadrant).
For mapping, the image pixels were segmented using the feature extraction tool (scale $=90$; merge level $=10$ ) of the ENVI software. Polygons were classified by visual interpretation for both periods. Figure 2 shows the aspect of land use and native vegetation observed for visual interpretation within the study site, taking the image of September 2015 as an example.

For comparison purposes, areas outside the experiment (Entre Rios Farm) that underwent changes in the land use and native vegetation were selected and analyzed for the response of biophysical indicators. For that, the average of the indicators values, represented in the pixels delimited by the classes of land use and native vegetation, was compared using the Tukey test ( $\alpha=0.05$ ). The same procedures were applied to the changes observed within the farm, with careful sample selection, observing the control points collected in the field. It is important to note that, in this area, the agriculture and livestock classes were grouped as "agro-livestock". This is because the crop-livestock integration started to be practiced as a productive activity in the farm between the analyzed periods. 

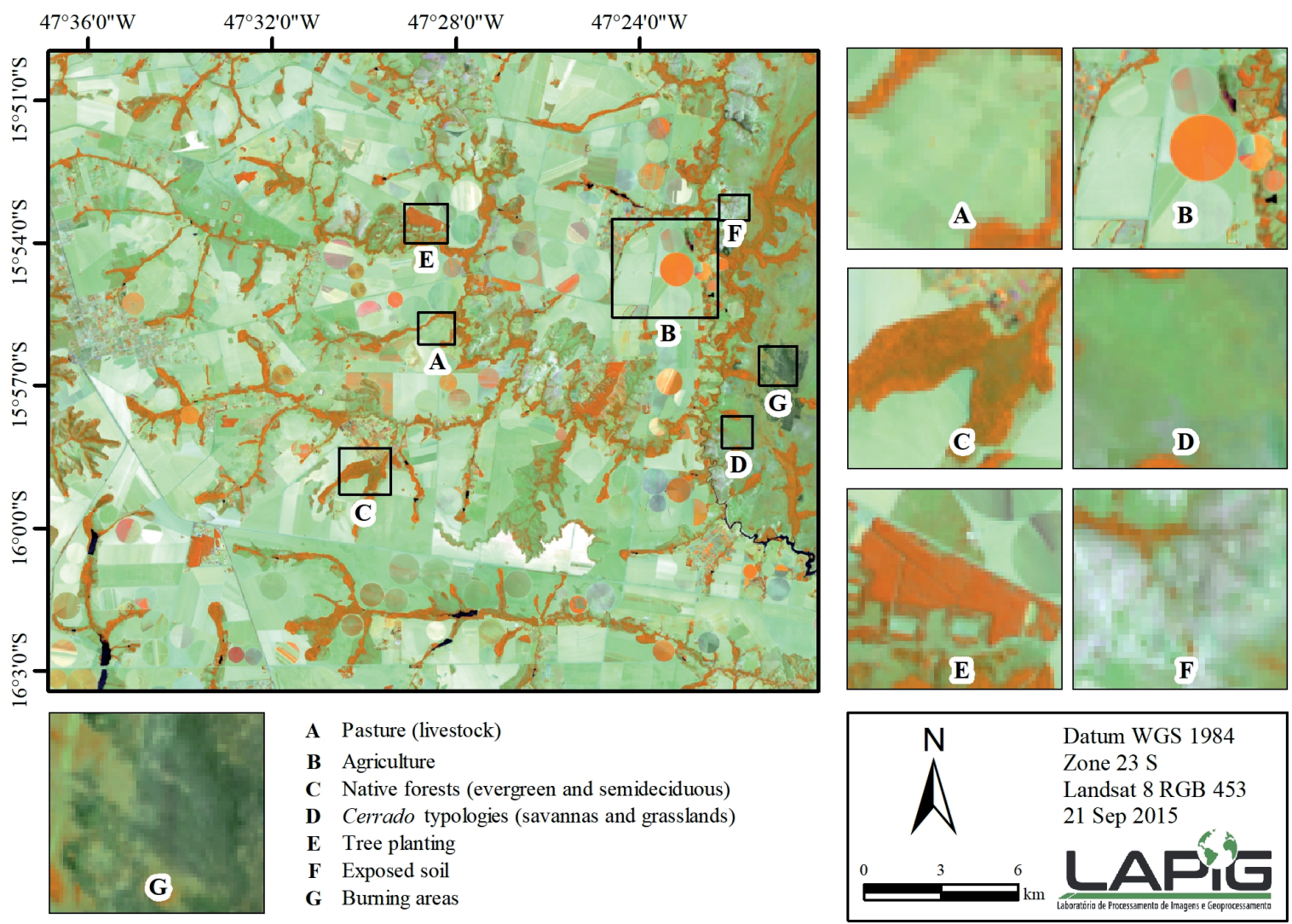

Figure 2. Aspects of land use and native vegetation examples observed for visual interpretation in the study area.

\section{RESULTS AND DISCUSSION}

Based on the mapping of the study area carried out for the two dates (November 2008 and September 2015), the agriculture and livestock classes already predominated in the region for the first date, while the remaining native vegetation was present in only $22 \%$ of the area. The changes that stood out the most in the landscape were selected for further statistical analysis of biophysical indicators by the SEBAL. Figure 3 shows the results of this mapping for the immediate surroundings of the farm, with delimitation of the landscapes that stood out the most, in terms of changes in land use and native vegetation, in the analyzed period.

Sano et al. (2009) evaluated the mapping accuracy for different land covers in the Cerrado and achieved a $71 \%$ accuracy, with confusion in the classification of native woody classes (forest and even shrub physiognomies) and classes of anthropic use, such as pasture and agriculture. However, native areas were well differentiated from anthropized areas with $90 \%$ of accuracy.
Knowing the possibility of error to which the classification is subjected, and with few changes observed in the mapping of this study, the comparison of the mappings for the surroundings of the farm between the two satellite images (from 2008 and 2015) does not assure significant changes in the land use and native vegetation, as there was no in loco validation. On the other hand, possible changes on the farm (Figure 4) were confirmed from the control points.

There was a reduction of $2.3 \%$ for the exposed soil class, and $2.4 \%$ for agriculture and livestock, together. On the contrary, there was an increase of $1.5 \%$ for pre-existing forest and savanna on the farm. Native and exotic tree planting areas totaled about 40 hectares $(3 \%)$ of the farm, where various planting arrangements are being experimented for economic and environmental purposes. These areas replaced those previously classified as agriculture, as noted in the Entre Rios Farm comparison map (Figure 4).

Noteworthy, the reduction of exposed soil areas, observed between 2008 and 2015, occurred in 

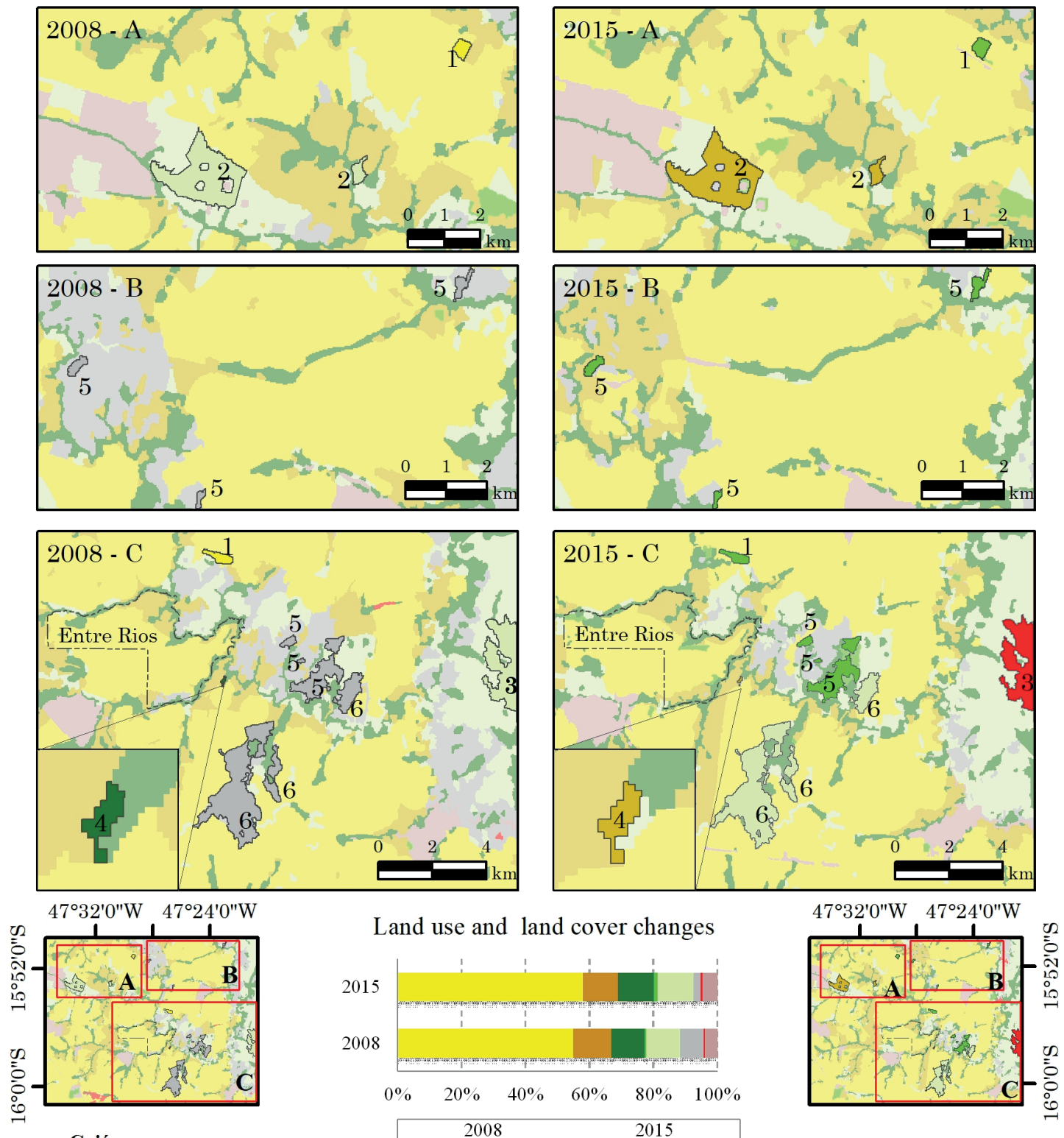

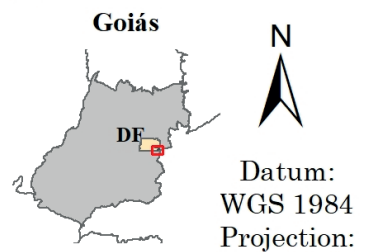

Projection: UTM LAPEG Zone:

\begin{tabular}{|l|cc|}
\cline { 2 - 3 } \multicolumn{1}{c|}{} & 2008 & 2015 \\
\hline $\mathrm{A}$ & $54.8 \%$ & $57.9 \%$ \\
$\square \mathrm{P}$ & $12.0 \%$ & $11.0 \%$ \\
$\square \mathrm{F}$ & $10.5 \%$ & $11.2 \%$ \\
$\square \mathrm{TP}$ & $0.4 \%$ & $1.2 \%$ \\
$\square \mathrm{Ce}$ & $10.6 \%$ & $11.2 \%$ \\
$\square \mathrm{ES}$ & $7.5 \%$ & $2.3 \%$ \\
$\square \mathrm{B}$ & $0.3 \%$ & $0.5 \%$ \\
$\square$ Others & $3.9 \%$ & $4.7 \%$ \\
\hline
\end{tabular}

\section{Delimited areas}

$$
\begin{aligned}
\mathrm{A} & \rightarrow \mathrm{TP} \\
\mathrm{Ce} & \rightarrow \mathrm{P} \\
\mathrm{Ce} & \rightarrow \mathrm{B} \\
\mathrm{F} & \rightarrow \mathrm{P} \\
\mathrm{ES} & \rightarrow \mathrm{TP} \\
\mathrm{ES} & \rightarrow \mathrm{Ce}
\end{aligned}
$$

Figure 3. Mapping of land use and native vegetation in the Entre Rios Farm and its surroundings, in 2008 and 2015. A: agriculture; ES: exposed soil; Ce: Cerrado typologies (savannas and grasslands); F: native forests (evergreen or semideciduous); B: burning areas; P: pastures; TP: tree planting.

recovered pastures. From the knowledge of the best management practices carried out in the farm (as a result of the Biomas Project), one can associate this reduction in recent years either to the search for soil conservation actions (e.g., by covering the soil with small foraging plants) or to the abandonment of the area, reoccupied either by native vegetation, pasture or by both management systems. 

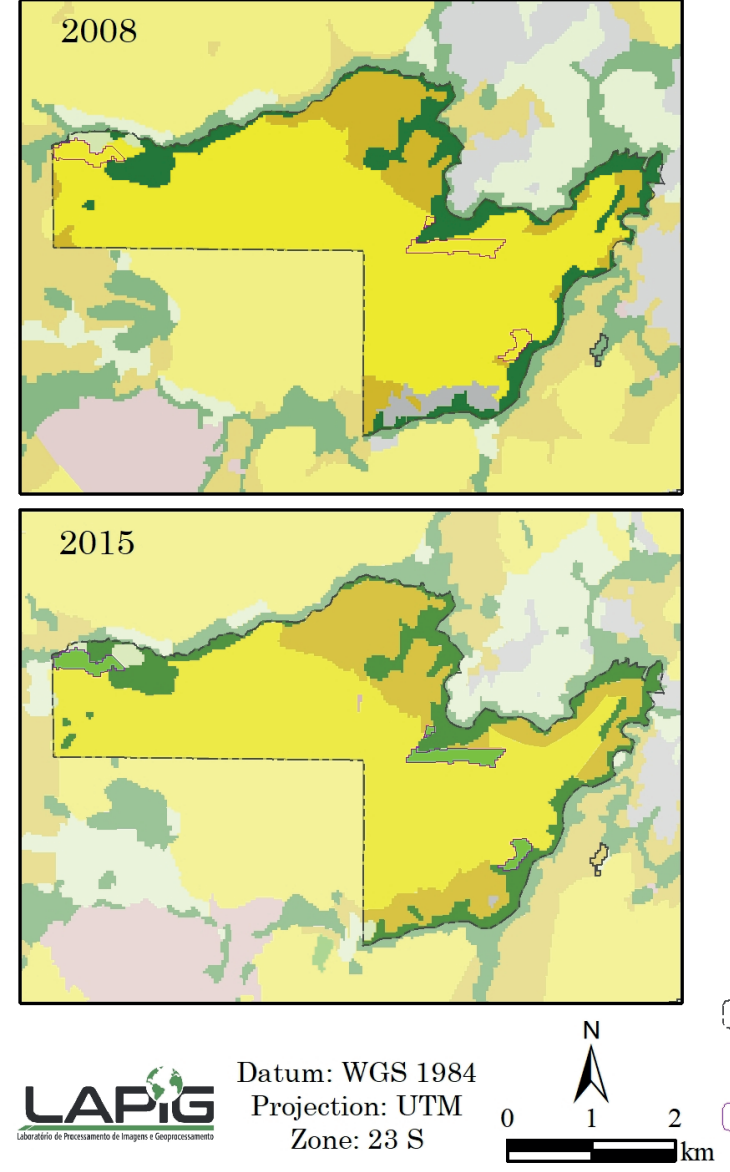

Land use and land cover changes

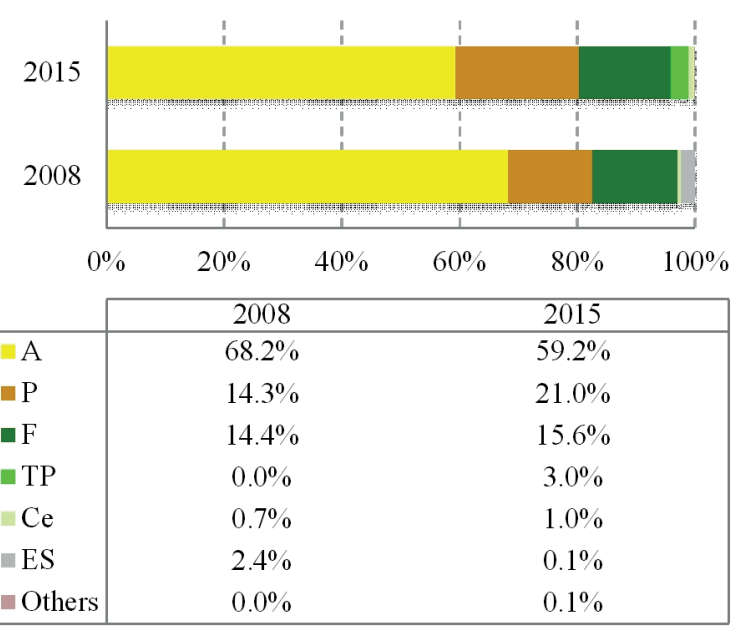

Entre Rios

Farm

Areas visited in the field

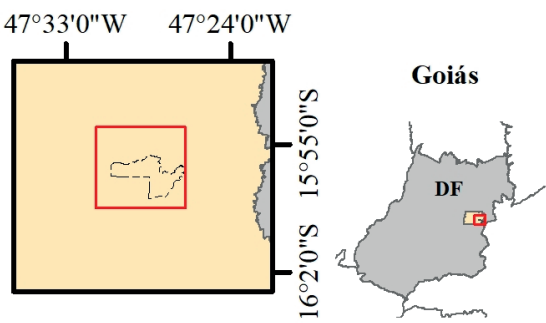

Figure 4. Mapping of land use and native vegetation in the Entre Rios Farm, in 2008 and 2015. A: agriculture; ES: exposed soil; Ce: Cerrado typologies (savannas and grasslands); F: native forests (evergreen or semideciduous); B: burning areas; $\mathrm{P}$ : pastures; TP: tree planting.

Table 3 presents the average of the results observed in this study for albedo, NDVI, surface temperature and evapotranspiration in the different fragments of land use and cover in the Entre Rios
Farm and its surroundings, in the analyzed periods (2008 and 2015).

The results of this study showed a reduction in albedo values for burning areas (10.2\%), followed

Table 3. Average values of albedo, surface temperature, NDVI and evapotranspiration for the selected areas surrounding the Entre Rios Farm, which showed changes in the land use and cover between the images analyzed for 2008 and 2015.

\begin{tabular}{|c|c|c|c|c|c|c|c|c|}
\hline \multirow{2}{*}{$\begin{array}{c}\text { Areas } \\
2008 \rightarrow 2015\end{array}$} & \multicolumn{2}{|c|}{$\begin{array}{c}\text { Albedo } \\
(\%)\end{array}$} & \multicolumn{2}{|c|}{$\begin{array}{l}\text { Surface temperature } \\
\left({ }^{\circ} \mathrm{C}\right)\end{array}$} & \multicolumn{2}{|c|}{ NDVI } & \multicolumn{2}{|c|}{$\begin{array}{l}\text { Evapotranspiration } \\
\left(\mathrm{mm} \mathrm{m}^{-2} \text { day }^{-1}\right)\end{array}$} \\
\hline & 2008 & 2015 & 2008 & 2015 & 2008 & 2015 & 2008 & 2015 \\
\hline $\mathrm{A} \rightarrow \mathrm{TP}$ & $17.1 \mathrm{Ca}^{*}$ & $14.2 \mathrm{Cb}$ & $37.4 \mathrm{Aa}$ & $31.8 \mathrm{~Eb}$ & $0.220 \mathrm{Ea}$ & $0.648 \mathrm{Ab}$ & $1.58 \mathrm{Ea}$ & $4.29 \mathrm{Bb}$ \\
\hline $\mathrm{Ce} \rightarrow \mathrm{P}$ & $15.3 \mathrm{Da}$ & $17.8 \mathrm{Bb}$ & $31.3 \mathrm{Ea}$ & $38.1 \mathrm{Bb}$ & $0.266 \mathrm{Ca}$ & $0.246 \mathrm{Db}$ & $3.33 \mathrm{Aa}$ & $2.72 \mathrm{~Eb}$ \\
\hline $\mathrm{Ce} \rightarrow \mathrm{B}$ & $14.3 \mathrm{Ea}$ & $10.2 \mathrm{~Eb}$ & $34.1 \mathrm{Ca}$ & $39.6 \mathrm{Ab}$ & $0.306 \mathrm{Ba}$ & $0.177 \mathrm{~Eb}$ & $2.71 \mathrm{Ba}$ & $3.17 \mathrm{~Eb}$ \\
\hline $\mathrm{F} \rightarrow \mathrm{P}$ & $14.5 \mathrm{DEa}$ & $20.4 \mathrm{Ab}$ & $32.0 \mathrm{Ea}$ & $36.1 \mathrm{Cb}$ & $0.413 \mathrm{Aa}$ & $0.266 \mathrm{Db}$ & $3.20 \mathrm{Aa}$ & $3.08 \mathrm{Da}$ \\
\hline $\mathrm{ES} \rightarrow \mathrm{TP}$ & $19.4 \mathrm{Aa}$ & $13.7 \mathrm{Db}$ & $33.6 \mathrm{Da}$ & $30.6 \mathrm{Fb}$ & $0.254 \mathrm{Da}$ & $0.629 \mathrm{Bb}$ & $2.45 \mathrm{Ca}$ & $4.62 \mathrm{Ab}$ \\
\hline $\mathrm{ES} \rightarrow \mathrm{Ce}$ & $17.4 \mathrm{Ba}$ & $14.3 \mathrm{Cb}$ & $36.2 \mathrm{Ba}$ & $34.4 \mathrm{Db}$ & $0.226 \mathrm{Ea}$ & $0.353 \mathrm{Cb}$ & $1.91 \mathrm{Da}$ & $3.92 \mathrm{Cb}$ \\
\hline
\end{tabular}

* Average values followed by different upper-case letters indicate a significant difference $(\alpha=0.05)$ in the biophysical indicators between the rows (i.e., between land uses for each year), while average values followed by different lower-case letters indicate a significant difference $(\alpha=0.05)$ in the biophysical indicators between columns (i.e., for land use and cover in 2008 and 2015). A: agriculture; P: pastures; Ce: Cerrado typologies (savannas and grasslands); F: native forests (evergreen or semideciduous); TP: tree planting; B: burning areas; ES: exposed soil. 
by forest areas (planted or native) and savanna areas (13.7 to $15.3 \%$ ), and, finally, exposed soil areas, agricultural areas and pastures (17.1 to $20.4 \%$ ), respectively. Other authors also found similar rates: 8 to $13 \%$ in burning areas (Lyons et al. 2008), these values being generally observed immediately after a more severe fire (Quintano et al. 2019); 11 to $15 \%$ in forest areas; and 13 to $20 \%$ in pastures (Querino et al. 2006, Giongo et al. 2009, Silva et al. 2015, Veloso et al. 2017); 13 to $26 \%$ in agricultural areas; around $13 \%$ in typical Cerrado vegetation (Giongo et al. 2009, Veloso et al. 2017); and 18 to $45 \%$ in exposed soil areas (Oliveira et al. 2013, Veloso et al. 2017).

As for NDVI, which can range from -1 (water) to 1 (maximum photosynthetic activity of vegetation), results are generally greater than 0.600 in dense forests (Bayma \& Sano 2015, Martins et al. 2015); between 0.260 and 0.460 in grassland and savanna regions of Cerrado (Trentin et al. 2013, Bayma \& Sano 2015); between 0.170 and 0.200 in pastures (Veloso et al. 2017); and between 0.250 and almost 0.800 in agricultural areas during the dry season, but greater than 0.550 when using irrigation (Trentin et al. 2013, Veloso et al. 2017).

In this study, the highest NDVI values occurred for tree plantations (average of 0.629). It is noteworthy that, depending on the vegetation density, NDVI may either saturate or have its value decreased in shaded areas such as primary forests (Ponzoni et al. 2012). However, the results were satisfactory for the purpose of characterizing such different land uses and covers. Even so, other vegetation indicators also generated by SEBAL, such as the Soil-Adjusted Vegetation Index (SAVI), can be analyzed in future studies due to their good adjustment for different thematic classes (Silva et al. 2019b).

When studying eucalyptus plantations, Almeida et al. (2015) found NDVI values greater than 0.500 for crops older than one year. Agricultural, exposed soil and livestock areas showed NDVI between 0.220 and 0.266, while Cerrado areas showed average NDVI between 0.266 and 0.353 . Evergreen or semideciduous forests, on the other hand, had an average NDVI of 0.413 . Burning areas had the lowest NDVI values, what was already expected due to the direct impact on their loss of photosynthetic activity. Souza et al. (2015) calculated NDVI values and showed that the Cerrado typologies may take from 94 to 100 days (with standard deviations of 46 to 50 days, respectively) to recover its vigor after burning.

The highest surface temperature occurred in burning areas $\left(39.6{ }^{\circ} \mathrm{C}\right)$. Livestock and agricultural areas showed average values between 36.1 and $38.1{ }^{\circ} \mathrm{C}$, while exposed soil and some Cerrado typologies showed values between 33.6 and $36.2^{\circ} \mathrm{C}$. In turn, native areas, including some of the denser Cerrado areas, had the lowest values $\left(30.6\right.$ to $\left.32^{\circ} \mathrm{C}\right)$. Corroborating these values, studies such as that by Eltz \& Rovedder (2005) also demonstrated that, between different soil covers, the more forested an area, the lower is the temperature close to the ground in that region. Cerrado typologies, and land uses such as agriculture and livestock, generally have higher values of surface temperature (Gusmão et al. 2013, Martins et al. 2015, Silva et al. 2015, Veloso et al. 2017).

Santos et al. (2017) analyzed the Caatinga biome using the SEBAL and showed that the daily evapotranspiration is similar for agricultural areas, grasslands and the characteristic vegetation of that biome, but higher for exposed soil areas and lower for areas with more dense canopies. This pattern tends to be the opposite of that observed for surface temperature. For example, Ning et al. (2017) also adopted the SEBAL in their methodology and showed how vegetation can influence measures of surface temperature and daily evapotranspiration, which are highly correlated $\left(\mathrm{R}^{2}>0.95\right)$ and inversely proportional.

Evapotranspiration was higher in planted forest $\left(>4.29 \mathrm{~mm} \mathrm{day}^{-1}\right)$ and lower in agricultural and exposed soil areas (1.58 to $\left.2.45 \mathrm{~mm} \mathrm{day}^{-1}\right)$. The other classes showed intermediate values. The results were consistent with the literature values for forest areas, which show evapotranspiration greater than $4 \mathrm{~mm}$ day $^{-1}$ or less than $3 \mathrm{~mm}^{\text {day }}{ }^{-1}$ in certain more extreme periods, in semideciduous or deciduous forests (Veloso 2014). However, areas with more sparse native vegetation, pastures or non-irrigated agricultural areas hardly present values greater than $2.5 \mathrm{~mm} \mathrm{day}^{-1}$ in the dry period (Veloso et al. 2017).

Finally, the same analysis was performed for the classes of land use and native vegetation mapped on the farm. Table 4 shows the results of this analysis. Native vegetation areas [native forests (evergreen or semideciduous) and Cerrado typologies (savannas and grasslands)] showed lower albedo and surface temperature and higher NDVI and evapotranspiration 
Table 4. Average values of albedo, surface temperature, NDVI and evapotranspiration for the land cover and use in the Entre Rios Farm, between the analyzed images for 2008 and 2015.

\begin{tabular}{|c|c|c|c|c|c|c|c|c|}
\hline \multirow{2}{*}{$\begin{array}{c}\text { Areas } \\
2008 \rightarrow 2015\end{array}$} & \multicolumn{2}{|c|}{$\begin{array}{l}\text { Albedo } \\
(\%)\end{array}$} & \multicolumn{2}{|c|}{$\begin{array}{c}\text { Surface temperature } \\
\left({ }^{\circ} \mathrm{C}\right)\end{array}$} & \multicolumn{2}{|c|}{ NDVI } & \multicolumn{2}{|c|}{$\begin{array}{l}\text { Evapotranspiration } \\
\left(\mathrm{mm} \mathrm{m}^{-2} \text { day }^{-1}\right)\end{array}$} \\
\hline & 2008 & 2015 & 2008 & 2015 & 2008 & 2015 & 2008 & 2015 \\
\hline $\mathrm{AP} \rightarrow \mathrm{TP}$ & $20.5 \mathrm{Aa}^{*}$ & $16.8 \mathrm{Bb}$ & $35.9 \mathrm{ABa}$ & $35.7 \mathrm{Ba}$ & $0.236 \mathrm{Da}$ & $0.360 \mathrm{Bb}$ & $1.72 \mathrm{Ca}$ & $3.37 \mathrm{Cb}$ \\
\hline $\mathrm{AP} \rightarrow \mathrm{AP}$ & $20.4 \mathrm{Aa}$ & $21.0 \mathrm{Ab}$ & $35.8 \mathrm{Ba}$ & $37.3 \mathrm{Ab}$ & $0.256 \mathrm{CDa}$ & $0.316 \mathrm{Cb}$ & $1.76 \mathrm{Ca}$ & $2.58 \mathrm{Db}$ \\
\hline $\mathrm{Ce} \rightarrow \mathrm{Ce}$ & $17.8 \mathrm{Ba}$ & $15.1 \mathrm{Cb}$ & $34.0 \mathrm{Ca}$ & $33.2 \mathrm{Ca}$ & $0.286 \mathrm{BCa}$ & $0.387 \mathrm{Bb}$ & $2.45 \mathrm{Ba}$ & $4.11 \mathrm{Bb}$ \\
\hline $\mathrm{F} \rightarrow \mathrm{F}$ & $14.4 \mathrm{Ca}$ & $13.7 \mathrm{Db}$ & $30.4 \mathrm{Da}$ & $31.0 \mathrm{Db}$ & $0.518 \mathrm{Aa}$ & $0.612 \mathrm{Ab}$ & $3.52 \mathrm{Aa}$ & $4.58 \mathrm{Ab}$ \\
\hline
\end{tabular}

* Average values followed by different upper-case letters indicate a significant difference $(\alpha=0.05)$ in the biophysical indicators between the rows (i.e., between land uses for each year), while average values followed by different lower-case letters indicate a significant difference $(\alpha=0.05)$ in the biophysical indicators between the columns (i.e., for land use and cover in 2008 and 2015). AP: agriculture or pasture; Ce: Cerrado typologies (savannas and grasslands); F: native forests (evergreen or semideciduous); TP: tree planting.

values. The opposite occurred in agro-livestock areas. In other words, planted forest areas have lower albedo and surface temperatures and higher NDVI and evapotranspiration values than agro-livestock areas. Noteworthy, the indicators were statistically equal across all areas in the image analyzed for 2008.

Therefore, it is important to highlight that planted areas came out of a closer relationship of biophysical indicators with agriculture in 2008, assuming values closer to those of the Cerrado typologies, as observed in 2015, for all indicators. This demonstrates the environmental role of planting trees. Notwithstanding, future analyses for native and exotic trees need to be conducted to understand the behavior of indicators in each case, as they may present different growth rates and interaction with the biophysical environment.

\section{CONCLUSIONS}

1. Remote sensing, in particular with the use of free satellite images and SEBAL modeling, enables the analysis of biophysical indicators characteristic of different types of land use and cover, and may be an auxiliary tool to monitor the conservation status of Cerrado ecosystems;

2. Planting tree species for the purpose of environmental regularization or sustainable production (with a focus on pasture recovery) increases the NDVI and evapotranspiration, while reducing the albedo and surface temperatures;

3. The analysis method that used SEBAL together with the processing and thematic classification of satellite images proved to be quite efficient, representing a more extensive area than it is normally evaluated in the field.

\section{ACKNOWLEDGMENTS}

The authors are grateful to the Biomas Project, for supporting the ground control point surveying and the management of the Entre Rios Farm; the assistance provided by the Image Processing and Geoprocessing Lab (LAPIG) of the Universidade Federal de Goiás (UFG); the Cerrado Research Group (GPC), for the processing and analysis of results; and the Critical Ecosystem Partnership Fund (CEPF - Cerrado), for supporting the development of the Cerrado Knowledge Platform (\#CEPF-103768). M.E.F. is a CNPq research productivity fellow (\#315699/2020-5).

\section{REFERENCES}

ALENCAR, A.; SHIMBO, J. Z.; LENTI, F.; MARQUES, C. B.; ZIMBRES, B.; ROSA, M.; ARRUDA, V.; CASTRO, I.; FERNANDES, M.; ALENCAR, I.; PIONTEKOWSKI, V.; RIBEIRO, V. Mapping three decades of changes in the Brazilian Savanna native vegetation using landsat data processed in the Google Earth engine platform. Remote Sensing, v. 12, e924, 2020.

ALMEIDA, A. Q.; RIBEIRO, A.; DELGADO, R. C.; RODY, Y. P.; OLIVEIRA, A. S.; LEITE, F. P. Índice de área foliar de Eucalyptus estimado por índices de vegetação utilizando imagens TM - Landsat 5. Floresta e Ambiente, v. 22, n. 3, p. 368-376, 2015.

BALA, G.; CALDEIRA, K.; WICKETT, M.; PHILLIPS, T. J; LOBELL, D. B.; DELIRE, C.; MIRIN, A. Combined climate and carbon-cycle effects of large-scale deforestation. Proceedings of the National Academy of Sciences, v. 104, n. 16, p. 6550-6555, 2007.

BASTIAANSSEN, W. G. M. Regionalization of surface flux densities and moisture indicators in composite terrain. 1995. Thesis (Ph.D. in Agricultural Engineering) Wageningen Agricultural University, Wageningen, 1995. 
BAYMA, A. P.; SANO, E. E. Séries temporais de índices de vegetação (NDVI e EVI) do sensor MODIS para detecção de desmatamentos no bioma Cerrado. Boletim de Ciências Geodésicas, v. 21, n. 4, p. 797-813, 2015.

BRASIL. Instituto Nacional de Meteorologia. Mapas das estações: A045 - Águas Emendadas. 2020. Available at: https://mapas.inmet.gov.br/. Access on: 17 Mar. 2021.

BRASIL. Lei $n^{\circ} 12.651$, de 25 de maio de 2012. Dispõe sobre a proteção da vegetação nativa; altera as Leis $n^{\circ}$ 6.938, de 31 de agosto de 1981, 9.393, de 19 de dezembro de 1996, e 11.428, de 22 de dezembro de 2006; revoga as Leis $n^{\circ} 4.771$, de 15 de setembro de 1965, e 7.754, de 14 de abril de 1989, e a Medida Provisória no 2.166-67, de 24 de agosto de 2001; e dá outras providências. Brasília, DF: Presidência da República, 2012.

BRASIL. Lei $n^{\circ} 12.805$, de 29 de abril de 2013. Insitui a política nacional de integração lavoura-pecuária-floresta e altera a Lei n ${ }^{\circ} 8.171$, de 17 de janeiro de 1991. Brasília, DF: Presidência da República, 2013.

BRASIL. Ministério do Meio Ambiente. Plano de ação para prevenção e controle do desmatamento e das queimadas no Cerrado (PPCerrado) e plano de ação para prevenção e controle do desmatamento na Amazônia legal (PPCDAm). Brasília, DF: MMA, 2018.

COE, M. T.; LATRUBESSE, E. M.; FERREIRA, M. E.; AMSLER, M. L. The effects of deforestation and climate variability on the streamflow of the Araguaia River, Brazil. Biogeochemistry, v. 105, n. 1, p. 119-131, 2011.

CONFEDERAÇÃO DA AGRICULTURA E PECUÁRIA DO BRASIL (CNA). Proteção e uso sustentável de paisagens dos biomas brasileiros: Projeto Biomas. Brasília, DF: CNA, 2009.

CRITICAL ECOSYSTEM PARTNERSHIP FUND (CEPF). Ecosystem profile Cerrado biodiversity hotspot: extended summary. Brasília, DF: Supernova, 2018.

CUMMING, G. S.; VON CRAMON-TAUBADEL, S. Linking economic growth pathways and environmental sustainability by understanding development as alternate social-ecological regimes. Proceedings of the National Academy of Sciences, v. 115, n. 38, p. 1-6, 2018.

ELTZ, F. L. F.; ROVEDDER, A. P. M. Revegetação e temperatura do solo em áreas degradadas no sudoeste do Rio Grande do Sul. Revista Brasileira de Agrociência, v. 11, n. 2, p. 193-200, 2005.

FERREIRA NETO, J. A. (coord.). Juntos pelo Araguaia: a vida que pulsa no coração do Brasil. Viçosa: Ed. UFV, 2020.

GIONGO, P. R.; PADOVANI, C. R.; VETTORAZZI, C. A. Variabilidade espacial e temporal do albedo obtido a partir de imagens MODIS na região do Pantanal. In: SIMPÓSIO BRASILEIRO DE SENSORIAMENTO REMOTO, 14., 2009, Natal. Anais... São José dos Campos: INPE, 2009. p. $4715-4722$.

GUSMÃO,A. C. V. e L.; SILVA, B. B. da; MONTENEGRO, S. M. G. L.; GALVÍNCIO, J. D.; OLIVEIRA, L. M. M. de. Índice de vegetação e temperatura da superfície no ecótono Ilha do Bananal por sensoriamento remoto. Revista de Geografia, v. 30, n. 3, p. 209-225, 2013.

KAZUHIRO, Y. Programa de cooperação nipo-brasileira para o desenvolvimento dos Cerrados - Prodecer. In: YOSHII, K.; CAMARGO, A. J. A. de; ORIOLI, A. L. (org.). Monitoramento ambiental nos projetos agrícolas do Prodecer. Planaltina, DF: Embrapa Cerrados, 2000. p. 27-32.

KUMAR, L.; SINHA, P.; TAYLOR, S.; ALQUARASHI, A. F. Review of the use of remote sensing for biomass estimation to support renewable energy generation. Journal of Applied Remote Sensing, v. 9, n. 1, p. 1-28, 2015.

LATRUBESSE, E. M.; ARIMA, E.; FERREIRA, M. E.; NOGUEIRA, S. H. M.; WITTMANN, F.; DIAS, M. S.; DAGOSTA, F. C. P.; BAYER, M. Fostering water resource governance and conservation in the Brazilian Cerrado biome. Conservation Science and Practice, v. 1, n. 1, p. 1-8, 2019.

LYONS, E. A.; JIN, Y.; RANDERSON, J. T. Changes in surface albedo after fire in boreal forest ecosystems of interior Alaska assessed using MODIS satellite observations. Journal of Geophysical Research, v. 113, G02012, 2008.

MARTINS, A. L.; CUNHA, C. R. da; PEREIRA, V. M. R.; DANELICHEN, V. H. de M.; MACHADO, N. G.; LOBO, F. de A.; MUSIS, C. R. de; BIUDES, M. S. Mudanças em índices biofísicos devido à alteração da cobertura do solo em área nativa de Cerrado em Mato Grosso. Ciência e Natura, v. 37, n. 4, p. 152-159, 2015.

MASCARENHAS, L. M. de A.; FERREIRA, M. E.; FERREIRA, L. G. Sensoriamento remoto como instrumento de controle e proteção ambiental: análise da cobertura vegetal remanescente na Bacia do Rio Araguaia. Sociedade \& Natureza, v. 21, n. 1, p. 5-18, 2009.

MENEZES, S. J. M. D. C. de; SEDIYAMA, G. C.; SOARES, V. P.; GLERIANI, J. M.; ANDRADE, R. G. Estimativa dos componentes do balanço de energia e da evapotranspiração em plantios de eucalipto utilizando o algoritmo SEBAL e imagem Landsat 5 - TM. Revista Árvore, v. 35, n. 3, p. 649-657, 2011.

NING, J.; GAO, Z.; XU, F. Effects of land cover change on evapotranspiration in the Yellow River delta analyzed with 
the SEBAL model. Journal of Applied Remote Sensing, v. 11, n. 1, p. 1-14, 2017.

OLIVEIRA, G. de; MORAES, E. C.; SHIMABUKURO, Y. E.; RUDORFF, B. F. T.; ALVALÁ, R. C. dos S.; SANTOS, T. V. dos. Avaliação do albedo em diferentes tipos de uso e cobertura da terra no sudoeste da Amazônia. In: SIMPÓSIO BRASILEIRO DE SENSORIAMENTO REMOTO, 16., Foz do Iguaçu, 2013. Anais... São José dos Campos: INPE, 2013. p. 8076-8713.

PONZONI, F. J.; SHIMABUKURO, Y. E.; KUPLICH, T. M. A vegetação e sua interação com a radiação eletromagnética. In: PONZONI, F. J.; SHIMABUKURO, Y. E.; KUPLICH, T. M. Sensoriamento remoto da vegetação. 2. ed. São Paulo: Oficina de Textos, 2012. p. 13-27.

QUERINO, C. A. S.; MOURA, C. A. L.; LYRA, R. F. da F.; MARIANO, G. L. Avaliação e comparação de radiação solar global e albedo com ângulo zenital na região amazônica. Revista Brasileira de Meteorologia, v. 21, n. 3, p. 42-49, 2006.

QUINTANO, C.; FERNANDEZ-MANSO, A.; MARCOS, E.; CALVO, L. Burn severity and post-fire land surface albedo relationship in Mediterranean forest ecosystems. Remote Sensing, v. 11, n. 19, p. 1-11, 2019.

SANO, E. E.; ROSA, R.; BRITO, J. L. S.; FERREIRA, L. G. Land cover mapping of the tropical Savanna region in Brazil. Environmental Monitoring Assessment, v. 166, n. 1, p. 113-124, 2009.

SANTOS, C. A. G.; SILVA, R. M. da; SILVA, A. M.; BRASIL NETO, R. M. Estimation of evapotranspiration for different land covers in a Brazilian semi-arid region: a case study of the Brígida River basin, Brazil. Journal of South American Earth Sciences, v. 74, n. 1, p. 54-66, 2017.

SARUKHÁN, J.; WHYTE, A. (ed.). Ecosystems and human well-being: synthesis. Washington, DC: Island Press, 2005.

SILVA, C. de O. F.; MANZIONE, R. L.; ALBUQUERQUE FILHO, J. L. Comparison of safer and metric-based actual evapotranspiration in a subtropical area of Brazil. Irriga, v. 1, n. 1, p. 48-55, 2019a

SILVA, F. A. M. da; ASSAD, E. D.; EVANGELISTA, B. A. Caracterização climática do bioma Cerrado. In: SANO, S. M.; ALMEIDA, S. P. de; RIBEIRO, J. F. Cerrado: ecologia e flora. Brasília, DF: Embrapa Informação Tecnológica, 2008. p. 69-88.

SILVA, L. C.; CUNHA, J. M.; MACHADO, N. G.; CAMPOS, M. C. C.; BIUDES, M. S. Estimativa do balanço de radiação por sensoriamento remoto de diferentes usos de solo no sudoeste da Amazônia brasileira. Sociedade \& Natureza, v. 27, n. 2, p. 341-356, 2015.

SILVA, V. S. da; SALAMI, G.; SILVA, M. I. O da; SILVA, E. A.; MONTEIRO JUNIOR, J. J.; ALBA, E. Methodological evaluation of vegetation indexes in land use and land cover (LULC) classification. Geology, Ecology, and Landscapes, v. 4, n. 2, p. 159169, 2019b.

SOUZA, G.; GURGEL, H. da C.; CIAMP, P. M. Dinâmica dos incêndios florestais no Cerrado do Distrito Federal por meio de imagens do sensor MODIS. In: SIMPÓSIO BRASILEIRO DE SENSORIAMENTO REMOTO, 17., 2015, João Pessoa. Anais... São José dos Campos: INPE, 2015. p. 819-826.

TRENTIN, A. B.; SALDANHA, D. L.; KUPLICH, T. M. Análise comparativa do NDVI em fitofisionomias na bacia hidrográfica do Rio São Marcos. Revista Geográfica Acadêmica, v. 7, n. 1, p. 5-16, 2013.

UNITED NATIONS (UN). The world's cities in 2018. 2018. Available at: https://www.un.org/en/events/ citiesday/assets/pdf/the_worlds_cities_in_2018_data booklet.pdf. Access on: 28 Mar. 2020.

UNITED STATES GEOLOGICAL SERVICE (USGS). Earth explorer. 2020. Available at: https://earthexplorer. usgs.gov. Access on: 17 Mar. 2021.

Veloso, G. A. Análise espaço temporal dos componentes do balanço de radiação, energia e evapotranspiração, usando técnicas de sensoriamento remoto em áreas irrigadas do Projeto Jaíba/MG. 2014. Dissertação (Mestrado em Geografia) - Instituto de Geografia, Universidade Federal de Uberlândia, Uberlândia, 2014.

VELOSO, G. A.; FERREIRA, M. E.; SILVA, B. B. Determinação da evapotranspiração real diária em áreas irrigadas do Projeto Jaíba (Minas Gerais, Brasil), mediante imagens Landsat 5 - TM. Revista Cerrados, v. 15, n. 1, p. 53-76, 2017.

VELOSO, G. A.; SILVA, L. A. P. da; FERREIRA, M. E. Análise do balanço de radiação e energia em áreas de veredas no norte de Minas Gerais, bioma Cerrado. Revista Cerrados, v. 18, n. 1, p. 220-247, 2020.

WOOD, S. L. R.; JONES, S. K.; JOHNSON, J. A.; BRAUMAN, K. A.; CHAPLIN-KRAMER, R.; FREMIER, A.; GIRVETZ, E.; GORDON, L. J.; KAPPEL, C. V.; MANDLE, L.; MULLIGAN, M.; O'FARRELL, P.; SMITH, W. K.; WILLEMEN, L.; ZHANG, W.; DECLERCK, F. A. Distilling the role of ecosystem services in the sustainable development goals. Ecosystem Services, v. 29, n. 1, p. 70-82, 2018. 